\title{
THE EFFECT OF FEED LEVEL DURING OESTRUS ON OVULATION RATE IN THE GILT
}

\author{
P. H. BROOKS, K. J. COOPER, G. E. LAMMING AND \\ D. J. A. COLE \\ University of Nottingham School of Agriculture, \\ Sutton Bonington, Loughborough, Leics.
}

(Received 18th May 1971, accepted 6th Fuly 1971)

\begin{abstract}
Summary. The effect of feed intake during the oestrous period and during previous oestrous cycles on ovulation rate, pituitary weight and pituitary LH potency, has been investigated. Control gilts were fed $1.8 \mathrm{~kg}$ food/day from puberty to the third oestrus. Increasing feed intake to $3.6 \mathrm{~kg}$ for 1 day, on the day following mating did not significantly affect ovulation rate, pituitary weight or residual LH potency. Increasing feed intake to $3.6 \mathrm{~kg}$ on the day of mating significantly $(P<0.05)$ increased ovulation rate by $I \cdot 3 \pm 0 \cdot 15$ ova, but did not affect pituitary weight or residual LH potency. Gilts fed $3.6 \mathrm{~kg}$ food/day from puberty to the third oestrus had significantly higher ovulation rates than gilts fed $1.8 \mathrm{~kg}$ food/day $(13.2$ versus 11.1 ova; $P<0.05)$, and significantly heavier dried pituitary glands $(47.8$ versus $38.3 \mathrm{mg} ; P<0.01)$. Residual pituitary LH potency was not affected by feed level.
\end{abstract}

\section{INTRODUCTION}

The experiments described in this paper were designed to study the effects of plane of nutrition between puberty and the third oestrus, and of feed intake during the third oestrous period on ovulation rate and early embryo mortality in the gilt.

A number of studies have shown that the ovulation rate of gilts is influenced by the plane of nutrition before oestrus, gilts allowed free access to food for 3 or more weeks before oestrus having higher ovulation rates than those on restricted feeding (Robertson, Casida, Grummer \& Chapman, 1951; Christian \& Nofziger, 1952; Self, Grummer \& Casida, 1955). Further, it has been shown that increasing the feed intake for as short a period as 6 days before oestrus increased ovulation rate (Zimmerman, Spies, Self \& Casida, 1960).

More recently, the work of Heap, Lodge \& Lamming (1967) indicated that, in the sow, ovulation rate may be influenced by changing the plane of nutrition during the oestrous period. Subsequently, Lodge \& Hardy (1968) showed that doubling the feed intake of gilts from 1.8 to $3.6 \mathrm{~kg}$ for 1 day only (at the first feed following service) significantly $(P<0.05)$ increased the mean number of piglets born from 8.9 to $10 \cdot 8$. They also found that increasing the feed allowance of gilts from 1.4 to $4.1 \mathrm{~kg}$ for a single feed given $12 \mathrm{hr}$ after the onset of oestrus significantly $(P<0.05)$ increased the mean ovulation rate from $12 \cdot 14$ to 14.71 . 
In a further experiment (Hardy \& Lodge, 1969), there was some evidence that ovulation rate at the post-lactational oestrous period was higher when sows were fed an extra $1.8 \mathrm{~kg}$. (Both groups received $2.3 \mathrm{~kg}$ food/day between weaning and mating.) These workers suggested that increasing feed intake during the oestrous period was rectifying the depressant effect of previous feed restriction on ovulation rate.

A similar effect has been reported in the rat. Cooper, Haynes \& Lamming (1970) found that reproductive capacity decreased with increases in the degree of nutrient restriction imposed, but that unrestricted feeding for $12 \mathrm{hr}$ immediately before the estimated time of ovulation significantly increased ovulation rate, but not the number of viable fetuses.

\section{MATERIALS AND METHODS}

\section{Animals and management}

The gilts used in these experiments were by Landrace boars and born to Landrace $\times$ Large White sows. The gilts were selected at approximately 170 days of age, and were housed in groups of twelve in deep-strawed yards. All the gilts were individually fed $1.8 \mathrm{~kg}$ of a breeding sow ration/day at a single feed

\section{TABLE 1}

COMPOSITION AND CHEMICAL ANALYSIS OF THE DIET

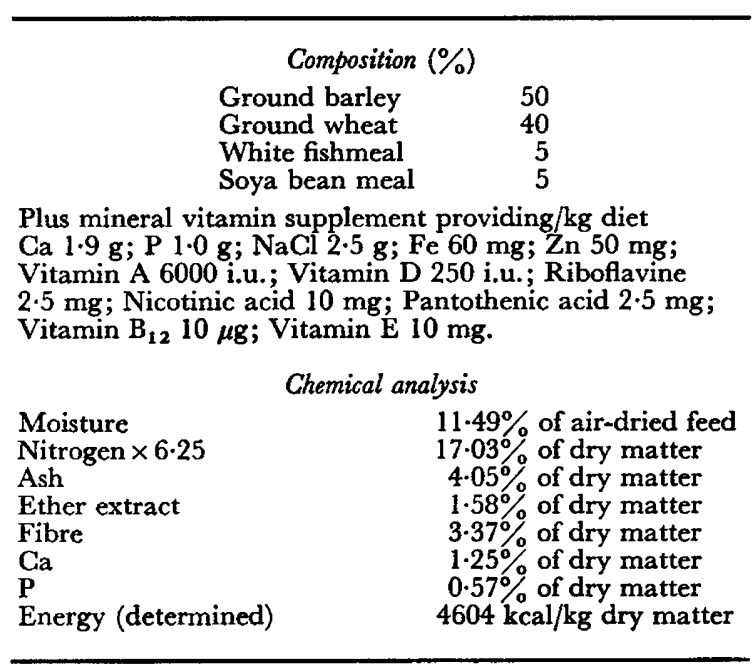

given in the morning. The composition of the ration is given in Table 1. The gilts had unlimited access to water.

All gilts were tested daily for oestrus using vasectomized boars. Puberty was defined as the day on which intromission by a vasectomized boar was permitted. The 1st day of oestrus as determined by boar acceptance was designated Day 1 of the cycle, or of pregnancy. 


\section{Experiment 1}

The experiment was a randomized block design. Thirty-six animals were arranged in three blocks of twelve on the basis of age at selection. Within each block of twelve animals, individuals were randomly allocated to one of three treatment groups at puberty. The treatments were as follows.

Control. These animals were fed $1.8 \mathrm{~kg}$ food/day from puberty to slaughter. This level is similar to that given in commercial practice.

High plane. Gilts in the 'high plane' group were fed $3.6 \mathrm{~kg}$ food/day from puberty to slaughter.

Extra nutrient intake $(E N I)$. Gilts in the ENI group were fed $1.8 \mathrm{~kg}$ food/day from puberty to slaughter. However, on Day 2 (i.e. day after first service) of the third oestrous period, the allowance was increased to $3.6 \mathrm{~kg}$ for 1 day only.

Each treatment group was further subdivided into two slaughter groups. Following the third oestrus, gilts were slaughtered either on Day 4 or Day 20 . All gilts slaughtered on Day 20 were mated with a fertile boar at the third oestrus. Two matings, on consecutive days were given if possible.

\section{Experiment 2}

This was also of a randomized block design. Thirty-six animals (three blocks of twelve allocated on the basis of age) were used. Within each block, four animals were allocated to the Control group and eight to the ENI group at puberty. The two treatments were as follows.

Control. The animals were fed as in Exp. 1, i.e. $1.8 \mathrm{~kg}$ food/day from puberty to slaughter.

$E N I$. Gilts on this treatment were fed as the controls, but the feed level was increased from $1.8 \mathrm{~kg}$ to $3.6 \mathrm{~kg}$ on Day 1 of the third oestrous period. The increased intake was achieved by giving the normal $1.8 \mathrm{~kg}$ daily feed and a second $1.8 \mathrm{~kg}$ feed following successful mating.

As in Exp. 1, gilts on each treatment were subdivided into two slaughter groups, and following the third oestrus were slaughtered on Day 4 or Day 20. All animals slaughtered on Day 20 were mated with fertile boars.

Slaughter procedure. The animals were stunned using a captive bolt pistol and killed by exsanguination from the jugular vein. Gilts killed on Day 4 were decapitated immediately, and their anterior pituitary glands were removed within $5 \mathrm{~min}$ of stunning. The pituitaries were freeze-dried and retained for subsequent assay for LH potency. The reproductive tracts were obtained on evisceration of the carcass and the ovaries were removed and stored in formol saline for histological examination. The uteri of gilts slaughtered on Day 20 were dissected and the number of viable embryos present recorded.

Ovarian histology. The ovaries were cut into $1-\mathrm{mm}$ sections and the number of CL (and in those pigs slaughtered on Day 4, the number of corpora albicantia remaining from the previous ovulation) were recorded. A random selection of ovaries from all treatment groups were serially sectioned at $7 \mu \mathrm{m}$ and examined for the presence of retained ova.

Anterior pituitary assays. The assay method used was the ovarian ascorbic acid depletion assay of Parlow (1958) employed as modified by Schmidt-Elmendorff \& Loraine (1962) with further minor modifications. The assay animals were 
intact, immature rats of Wistar origin, 28 to 35 days old. Each animal received a subcutaneous injection of 50 i.u. PMSG and $72 \mathrm{hr}$ later, a subcutaneous injection of 30 i.u. HCG. Assay of anterior pituitary LH potency was carried out 7 days after the injection of HCG. The standard and unknown materials were dissolved in $0.9 \% \mathrm{NaCl}$ solution and $1 \mathrm{ml}$ was injected intravenously into the jugular vein of each assay animal. The animals were killed in ether $4 \mathrm{hr} \pm 5$ min after the intravenous injection and the left ovary was removed. Each ovary was weighed, and stored overnight in the dark at $-15^{\circ} \mathrm{C}$. The following day, each ovary was homogenized with $10 \mathrm{ml}$ of a freshly prepared solution of $2.5 \%$ metaphosphoric acid and centrifuged to remove tissue débris. Duplicate $3 \cdot 5-\mathrm{ml}$ aliquots of the supernatant were taken and each aliquot added to a tube containing $4 \mathrm{ml}$ of dye solution. This solution was a mixture of $0.03 \% 2,6-$ dichlorophenolindophenol and $4.53 \%$ sodium acetate (adjusted to $\mathrm{pH} 7.0$ with acetic acid) in the ratio of $1: 7$. The optical density of the resulting solution was measured colorimetrically at $520 \mathrm{~m} \mu$ with a $1 \cdot 0-\mathrm{cm}$ glass cell and a blue filter. The ascorbic acid concentration of each ovary was calculated from a standard curve.

Quantitative assays were carried out with pooled anterior pituitaries using a four-point design, employing two doses of standard (S) and unknown (U), respectively. In each assay, six animals were used for each dose level of $S$ and $U$. The $\log$ dose interval was $\log _{10} 5$. The doses of $\mathrm{S}$ used were 0.8 and $4.0 \mu \mathrm{g}$ NIH-LH-S14 and the doses of U were 0.5 and $2.5 \mathrm{mg}$ dried pituitary tissue.

Statistical analysis. All data apart from assays were analysed using the method of Kempthorne (1952) for a two-way classification with unequal numbers. In Exp. 1, where significant treatment effects were obtained, individual differences were examined by Multiple Range Test (Duncan, 1955) using the critical values calculated by Harter (1960).

For each assay, the ascorbic acid content of each ovary was adjusted by covariance analysis, as recommended by Sakiz \& Guillemin (1963). The validity, index of precision $(\lambda)$, relative potency, and fiducial limits at $P=0.95$ were calculated for each assay using standard methods.

\section{RESULTS}

\section{Experiment 1}

The number of animals providing data at various stages is shown in Table 2. All the selected animals reached puberty. Two gilts became acyclic following their second oestrus and were discarded. At slaughter, thirteen of the seventeen animals mated were found to be pregnant. However, one of these animals was found to be a pregnant intersex (Scofield, Cooper \& Lamming, 1969) and was therefore excluded from the data.

The results obtained are summarized in Table 3. There was no significant difference in the mean age and weight of the three treatment groups at puberty. At mating, the animals on a high plane of feeding were $12 \mathrm{~kg}$ heavier than the control group and $15 \mathrm{~kg}$ heavier than the ENI group $(P<0.05)$. Serial sectioning of the ovaries selected from all treatment groups failed to reveal any ova retained in GL. The CL counts were therefore taken as a reliable estimate of 
TABLE 2

NUMBERS OF ANIMALS PROVIDING DATA AT THE VARIOUS STAGES IN EXPERIMENT 1

\begin{tabular}{l|cc|cc|cc}
\hline \multicolumn{1}{c|}{ Treatment: } & \multicolumn{2}{|c|}{ Control } & \multicolumn{2}{c|}{ High plane } & \multicolumn{2}{c}{ ENI } \\
\multicolumn{1}{c|}{ Slaughter group: } & Day 4 & Day 20 & Day 4 & Day 20 & Day 4 & Day 20 \\
\hline No. of gilts at puberty & 6 & 6 & 6 & 6 & 6 & 6 \\
No. of gilts reaching third oestrus & 5 & 6 & 6 & 6 & 6 & 5 \\
No. mated & - & 6 & - & 6 & - & 5 \\
No. pregnant at Day 20 & - & 4 & - & 4 & - & $4^{*}$ \\
\hline
\end{tabular}

$\mathrm{ENI}=$ Extra nutrient intake.

* One pregnant intersex gilt excluded from data.

TABLE 3

EFFECT OF PLANE OF NUTRITION AND FEED LEVEL AT OESTRUS ON REPRODUCTION IN THE GILT (EXPERIMENT 1)

\begin{tabular}{|c|c|c|c|c|}
\hline & \multicolumn{3}{|c|}{ Treatment } & \multirow{2}{*}{$\begin{array}{c}\text { Standard } \\
\text { error of } \\
\text { differences } \\
\text { between } \\
\text { means* }\end{array}$} \\
\hline & Control & High plane & $E \mathcal{N I}$ & \\
\hline Mean pubertal age (days) & $177 \cdot 7$ & $210 \cdot 8$ & $199 \cdot 5$ & $19 \cdot 63$ \\
\hline Mean pubertal weight $(\mathrm{kg})$ & $91 \cdot 7$ & $92 \cdot 0$ & $87 \cdot 8$ & $2 \cdot 18$ \\
\hline $\begin{array}{l}\text { Mean weight at third oestrus } \\
(\mathrm{kg})\end{array}$ & $106 \cdot 5^{1}$ & $118 \cdot 2^{1,2}$ & $103 \cdot 1^{2}$ & $3 \cdot 94$ \\
\hline $\begin{array}{l}\text { Mean percentage weight } \\
\text { change from first to third } \\
\text { oestrus }\end{array}$ & $15 \cdot 0$ & $30 \cdot 3$ & $15 \cdot 5$ & - \\
\hline $\begin{array}{l}\text { Mean ovulation rate of } \\
\text { second oestrus }\end{array}$ & $9 \cdot 9$ & $11 \cdot 8$ & $10 \cdot 3$ & $0 \cdot 96$ \\
\hline $\begin{array}{l}\text { Mean ovulation rate of } \\
\text { third oestrus }\end{array}$ & $11 \cdot 1^{1}$ & $13 \cdot 2^{1}$ & $11 \cdot 7$ & $0 \cdot 34$ \\
\hline $\begin{array}{l}\text { Mean number of viable } \\
\text { embryos at Day } 20\end{array}$ & $9 \cdot 3$ & $10 \cdot 0$ & $10 \cdot 8$ & $2 \cdot 33$ \\
\hline Embryo mortality $\dagger$ & $14 \cdot 8$ & $15 \cdot 5$ & $8 \cdot 8$ & - \\
\hline $\begin{array}{l}\text { Mean dried pituitary } \\
\text { weight (mg) }\end{array}$ & $38 \cdot 3^{1}$ & $47 \cdot 8^{1,2}$ & $37 \cdot 7^{2}$ & $2 \cdot 2$ \\
\hline $\begin{array}{l}\text { Mean pituitary LH } \\
\text { potency/mg }(\mu \mathrm{g} S)\end{array}$ & $\begin{array}{c}2 \cdot 0 \\
(1 \cdot 3 \text { to } 3 \cdot 2)\end{array}$ & $\begin{array}{c}2 \cdot 5 \\
(1 \cdot 6 \text { to } 3 \cdot 9)\end{array}$ & $\begin{array}{c}2 \cdot 6 \\
(1 \cdot 2 \text { to } 4.4)\end{array}$ & - \\
\hline $\begin{array}{l}\text { Total pituitary LH } \\
\text { potency/mg ( } \mu \mathrm{g} \mathrm{S})\end{array}$ & $\begin{array}{c}77 \cdot 6 \\
(50 \cdot 9 \text { to } 146 \cdot 8)\end{array}$ & $\begin{array}{c}117 \cdot 8 \\
(77 \cdot 7 \text { to } 184 \cdot 5)\end{array}$ & $\begin{array}{c}96 \cdot 6 \\
(45 \cdot 4 \text { to } 166 \cdot 8)\end{array}$ & - \\
\hline Index of precision $(\lambda)$ & 0.22 & 0.22 & $0 \cdot 22$ & \\
\hline
\end{tabular}

ENI $=$ Extra nutrient intake.

$\mathrm{S}=$ Standard (see text).

* Due to unequal subclass numbers, there are slight variations in the standard errors of differences between means. An average figure is therefore presented.

$\dagger$ Ratio of embryos to CL expressed as a percentage.

1,2 Means with the same suffix differ at $P<0.05$. 
ovulation rate. The ovulation rate of the 'high plane' animals was significantly greater than that of controls $(P<0.05$, see Table 3$)$. The higher ovulation rate of the 'high plane' gilts was apparent at second oestrus although in this case the difference was not significant.

\section{TABLE 4}

NUMBERS OF ANIMALS PROVIDING DATA AT THE VARIOUS STAGES IN EXPERIMENT 2

\begin{tabular}{l|cc|cc}
\multicolumn{1}{c|}{ Treatment: } & \multicolumn{2}{c|}{ Control } & \multicolumn{2}{c}{ ENI } \\
\multicolumn{1}{c|}{ Slaughter group: } & Day 4 & Day 20 & Day 4 & Day 20 \\
\hline No. of gilts at puberty & 6 & 6 & 12 & 12 \\
No. of gilts reaching third oestrus & 5 & 5 & 10 & 10 \\
No. mated & - & 5 & - & 10 \\
No. pregnant at Day 20 & - & 3 & - & 10 \\
\hline
\end{tabular}

$\mathrm{ENI}=$ Extra nutrient intake.

TABLE 5

EFFEGT OF FEED LEVEL AT OESTRUS ON REPRODUCTION IN THE GILT (EXPERIMENT 2)

\begin{tabular}{|c|c|c|c|}
\hline & \multicolumn{2}{|c|}{ Treatment } & \multirow{2}{*}{$\begin{array}{c}\text { Standard } \\
\text { error of } \\
\text { differences } \\
\text { between } \\
\text { means }\end{array}$} \\
\hline & Control & ENI & \\
\hline Mean pubertal age (days) & $224 \cdot 8$ & $229 \cdot 1$ & $2 \cdot 61$ \\
\hline Mean pubertal weight (kg) & $94 \cdot 8$ & $102 \cdot 6$ & 4.07 \\
\hline Mean weight at third oestrus $(\mathrm{kg})$ & $108 \cdot 9$ & $117 \cdot 7$ & $4 \cdot 18$ \\
\hline $\begin{array}{l}\text { Mean percentage weight change from first to } \\
\text { third oestrus }\end{array}$ & $15 \cdot 4$ & $14 \cdot 2$ & - \\
\hline Mean ovulation rate at second oestrus & $11 \cdot 1$ & $11 \cdot 4$ & $0 \cdot 47$ \\
\hline Mean ovulation rate at third oestrus & $11 \cdot 9 *$ & $13 \cdot 2 *$ & 0.15 \\
\hline Mean number of viable embryos at Day 20 & $10 \cdot 7$ & $10 \cdot 6$ & \\
\hline Embryo mortality $\dagger$ & 5.8 & $14 \cdot 9$ & - \\
\hline Mean dried pituitary weight (mg) & 43.4 & $42 \cdot 9$ & 3.50 \\
\hline Mean pituitary LH potency/mg ( $\mu \mathrm{g} \mathrm{S}$ ) & $\begin{array}{c}3 \cdot 2 \\
(2 \cdot 3 \text { to } 4 \cdot 6)\end{array}$ & $\begin{array}{c}2.5 \\
(1.8 \text { to } 3.6)\end{array}$ & - \\
\hline Total pituitary LH potency ( $\mu \mathrm{g} S$ ) & $\begin{array}{c}138.9 \\
(99 \cdot 8 \text { to } 199 \cdot 6)\end{array}$ & $\begin{array}{c}107 \cdot 3 \\
(77 \cdot 2 \text { to } 154 \cdot 4)\end{array}$ & - \\
\hline Index of precision $(\lambda)$ & 0.19 & 0.19 & \\
\hline
\end{tabular}

ENI $=$ Extra nutrient intake.

$\mathrm{S}=$ Standard (see text).

* Significantly different at $P<0.05$, all other differences between means were not significant.

$\dagger$ Ratio of embryos to corpora lutea expressed as a percentage.

Notwithstanding the significant differences in ovulation rate at third oestrus, the number of viable embryos at Day 20 was not significantly influenced by treatment. However, the number of animals providing data on embryo numbers was small (Table 2). 'High plane' gilts had a significantly greater mean dried pituitary weight, but the differences in LH potency/mg pituitary weight and total pituitary LH content were not significant. 
Experiment 2

The number of animals providing data at the various stages is shown in Table 4. Six of the selected animals failed to reach puberty and hence provided no data. Examination of these animals at autopsy showed that five had ovaries containing cL suggesting that they had cycled without showing psychic heat. Thirteen of the fifteen gilts mated were pregnant at slaughter.

The results are summarized in Table 5 . There were no significant differences in pubertal weights or ages, nor was there any significant difference in the weight gain between puberty and the third oestrus on the two treatments. Although there was no significant difference in ovulation rate at the second oestrus, the ENI group had a significantly higher $(P<0.05)$ ovulation rate at the third oestrus than the controls (13.2 versus 11.9 ), but this difference was not reflected in the number of viable embryos at Day 20. Treatment did not significantly affect either mean dried pituitary weight, pituitary LH potency/mg pituitary weight or total pituitary LH content.

\section{DISCUSSION}

Serial sectioning of selected ovaries from all treatment groups in both experiments supported the results of Perry (1961), who found no polyovular or anovular follicles and no CL with retained ova. Therefore, an accurate determination of the number of CL during early pregnancy was taken to be representative of ovulation rate since each CL can, for practical purposes, be assumed to represent one ovulated ovum. The results of Exp. 1 confirm previous reports (Robertson et al., 1951; Christian \& Nofziger, 1952; Self et al., 1955) that a high plane of nutrition following puberty increases ovulation rate but not necessarily litter size. Increasing feed intake from 1.8 to $3.6 \mathrm{~kg}$ /day between puberty and the third oestrus significantly $(P<0.05)$ increased ovulation rate. Furthermore, there were indications that a high plane of nutrition for one cycle length only, that is from puberty to the second oestrus, resulted in a higher ovulation rate, though the increase was not significant in this experiment.

Increasing feed intake on Day 2 of the cycle only (ENI group) did not produce a significant increase in ovulation rate, but here the extra feed intake probably preceded ovulation by only a few hours and thus was possibly too close to the time of ovulation. In Exp. 2, the feed intake was increased on Day 1, allowing a longer period between the time of increased feed intake and ovulation. This resulted in a significant increase in ovulation rate, confirming the results obtained by Lodge \& Hardy (1968) for the number of ova released but not for litter size. In the experiments described here, the number of animals on which estimates of embryo mortality were based was too small to draw firm conclusions but the data available revealed no significant effect of treatment for this aspect of the study.

The pituitary LH potencies recorded in the two experiments represent the amount of $\mathrm{LH}$ remaining in the anterior pituitary approximately $70 \mathrm{hr}$ after the preovulatory release of gonadotrophins. The residual levels of $L H$ found in these experiments were unaffected by nutrition and remained constant at a basal concentration of between 2 and $4 \mu \mathrm{g}$ of standard/mg pituitary tissue. 
Further studies will be needed to elucidate whether an alteration of pituitary hormone secretion is implicated in the ovarian response to transient increases in feed intake.

The increase in ovulation rate following ENI on Day 1, but not on Day 2, of oestrus suggests that the timing of the increased feed intake is critical. The ovulatory release of gonadotrophins takes place at the onset of behavioural oestrus (Niswender, Reichert \& Zimmerman, 1970). Further, the final maturation of the follicles destined to rupture occurs during the period between the release of the ovulatory hormones and ovulation. Since the effect of a single increment of extra nutrients on the pituitary and ovary is likely to be of a limited duration, the maximum increase in ovulation rate will only be obtained when the ENI is supplied close to ovulation while still allowing sufficient time for any pituitary or ovarian changes to take place. The optimum time appears to be around the time of the ovulatory release of gonadotrophins in the pig. However, while the number of ova released determines the maximum potential litter size, increase in ovulation rate will not necessarily result in increases in the number of piglets born.

\section{ACKNOWLEDGMENTS}

This work was conducted while two of us (P. H. Brooks and K. J. Cooper) were receiving postgraduate scholarships from the Meat and Livestock Commission. The authors would like to express their thanks to Mr H. L. Back for help with statistical analysis of the results and to $\mathrm{Mr}$ J. Corbett for technical assistance.

\section{REFERENCES}

Christian, R. E. \& Nofziger, J. C. (1952) Puberty and other reproductive phenomena in gilts as affected by plane of nutrition. (Abstract). J. Anim. Sci. 11, 789.

Cooper, K. J., Haynes, N. B. \& Lamming, G. E. (1970) Effects of unrestricted feeding during oestrus on reproduction in the underfed female rat. 7. Reprod. Fert. 22, 293.

Duncan, D. B. (1955) Multiple Range and Multiple F tests. Biometrics, $11,1$.

HARDy, B. \& LODGE, G. A. (1969) The influence of nutrition during post-lactational oestrus on ovulation rate in the sow, and the accuracy of corpora lutea counts in estimating ovulations. 7 . Reprod. Fert. 19, 555.

Harter, H. L. (1960) Critical values for Duncan's new Multiple Range test. Biometrics, $16,671$.

Heap, F. G., Lodge, G. A. \& Lamming, G. E. (1967) The influence of plane of nutrition in early pregnancy on the survival and development of embryos in the sow. $\mathbf{F}$. Reprod. Fert. 13, 269.

Kempthorne, O. (1952) The design and analysis of experiments. Wiley, New York.

LODGE, G. A. \& HARDY, B. (1968) The influence of nutrition during oestrus on ovulation rate in the sow. F. Reprod. Fert. 15, 329.

Niswender, G. D., Reichert, L. E. \& Zimmerman, D. R. (1970) Radioimmunoassay of serum levels of luteinizing hormone throughout the estrous cycle in pigs. Endocrinology, 87, 576.

Parlow, A. F. (1958) A rapid bioassay method for LH and factors stimulating LH secretion. Fedn Proc. Fedn Am. Socs exp. Biol. 17, 402.

Perry, J. S. (1961) Prenatal mortality due to non-infective agents. 7. Reprod. Fert. 2, 531.

Robertson, G. L., Gasida, L. E., Grummer, R. H. \& Ghapman, A. B. (1951) Some feeding and management factors affecting age at puberty and related phenomena in Chester White and Poland China gilts. F. Anim. Sci. 10,841.

SAKIz, E. \& GuIllemin, R. (1963) On the method of ovarian ascorbic acid depletion as a test for luteinizing hormone (LH). Endocrinology, 72, 804.

Schmidt-Elmendorff, H. \& LoRAine, J. A. (1962) Some observations on the ovarian ascorbic acid depletion method as a test for LH activity. 7 . Endocr. 23, 413. 
Scofield, A. M., Cooper, K. J. \& Lamming, G. E. (1969) The distribution of embryos in intersex pigs. 7. Reprod. Fert. 20, 161.

Selp, H. L., Grummer, R. H. \& CAsida, L. E. (1955) The effects of various sequences of full and limited feeding on the reproductive phenomena in Chester White and Poland China gilts. J. Anim. Sci. $14,573$.

Zimmerman, D. R., Spies, H. G., Self, H. L. \& Casida, L. E. (1960) Ovulation rate in swine as affected by increased energy intake just prior to ovulation. J. Anim. Sci. 19, 295. 